\title{
CLINICAL, NEUROVASCULAR AND NEUROPATHOLOGICAL FEATURES IN SNEDDON'S SYNDROME
}

\author{
Jaqueline Luvisotto Marinho', Élcio Juliato Piovesan², Moacir Pereira Leite Neto², \\ Luiz Roberto Kotze ${ }^{3}$, Lúcia de Noronha ${ }^{3}$, Carlos Alexandre Twardowschy², \\ Marcos Christiano Lange ${ }^{2}$, Rosana Hermínia Scola², Viviane H. Flumignan Zétola², \\ Edison Matos Nóvak², Lineu César Werneck ${ }^{2}$
}

\begin{abstract}
Sneddon's syndrome (SS) is characterized by ischemic cerebrovascular episodes and livedo reticularis. It is more common in young women and can also be associated with valvulopathy, a history of spontaneous abortion, renal involvement and vascular dementia. We describe three cases of young women with this disease. The patients had repeated ischemic cerebral episodes, livedo reticularis and thrombocytopenia. CT and MRI showed strokes and cerebral atrophy. Autopsy in one of the patients revealed cerebral infarctions. Anticardiolipin antibodies were detected in two patients. Antiphospholipid antibodies may be found in some patients with ischemic cerebrovascular events and livedo reticularis. SS may thus be associated with antiphospholipid syndrome. We described three new cases of SS and discuss the pathophysiology of this disease.
\end{abstract}

KEY WORDS: antiphospholipid syndrome, cerebrovascular diseases, neuroimaging, neuropathology, Sneddon's syndrome.

\begin{abstract}
Características clínicas, neurovasculares e neuropatológicas na síndrome de Sneddon
RESUMO - A síndrome de Sneddon é caracterizada por episódios cerebrovasculares isquêmicos e livedo reticular, sendo mais comum em mulheres jovens, e pode também apresentar valvulopatia, história de aborto, envolvimento renal e demência vascular. Descrevemos três mulheres jovens com esta entidade. Os pacientes apresentavam história de ataques isquêmicos cerebrais, livedo reticular e trombocitopenia. Tomografia computadorizada e ressonância magnética de crânio mostraram infartos e atrofia cerebral nos pacientes estudados. A autópsia revelou em um dos pacientes presença de infartos cerebrais. Anticorpos anticardiolipina foram observados em duas pacientes. Há pacientes com eventos cerebrovasculares isquêmicos e livedo reticular nos quais anticorpos antifosfolípides são detectados. Então SS pode estar associada com a síndrome antifosfolípide, porém em alguns pacientes estes anticorpos não são detectados. Nós descrevemos três novos casos de SS e discutimos os mecanismos fisiopatológicos desta síndrome.
\end{abstract}

PALAVRAS-CHAVE: doenças cerebrovasculares, neuroimagem, neuropatologia, síndrome antifosfolípide, síndrome de Sneddon.

Sneddon's syndrome (SS) is characterized by the combination of ischemic cerebrovascular episodes and a widespread livedoid eruption. Although this association was first described in a patient in 1960 by Champion and Rook ${ }^{1}$, only later, in 1965, did Sneddon suggest this association in six new cases $^{2}$. SS is more common in women between 20 and 42 years of age ${ }^{3}$ and can be accompanied by other manifestations such as systemic hypertension, acrocyanosis, Raynaud's phenomenon ${ }^{4}$, secondary headaches ${ }^{3-5}$, ve- nous thrombosis ${ }^{4}$, valvulopathy ${ }^{4}$, a history of spontaneous abortions $s^{3,6}$, seizures ${ }^{3,7}$, renal involvement ${ }^{8}$, and vascular dementia9,10. Antiphospholipid antibodies can also be found at a highly variable frequen$\mathrm{Cy}^{3,4,11}$.

The frequency of headache is not significantly higher in persons with positive anti-phospholipid antibodies compared with the negative cohort ( $43 \%$ vs. $32 \%$ ), with a female to male ratio of $3.5: 1$. The association with SS and primary headaches, such as mi-

\footnotetext{
${ }^{1}$ Ribeirão Preto Faculty of Medicine, University of São Paulo, Ribeirão Preto SP, Brazil; ${ }^{2}$ Department of Clinical Medicine, Neurology Division, Hospital de Clínicas, Federal University of Paraná, Curitiba PR, Brazil (UFPR); ${ }^{3}$ Department of Pathology, Hospital de Clínicas, UFPR, Brazil.
}

Received 15 September 2006, received in final form 28 November 2006. Accepted 6 February 2007. 
graine occurs in $27.5 \%$ of the cases when SS is followed of headache ${ }^{12}$. Livedo reticularis often precedes the cerebrovascular events, whose onset usually occurs before the age of 45 years. These events consist of ischemic strokes or transient ischemic attacks, which affect mainly medium-sized arteries and are seen particularly in the territory of the middle and posterior cerebral artery ${ }^{4,5,13-15}$. Intracerebral, subarachnoid or intraventricular hemorrhages have also been reported ${ }^{16,17}$.

In this paper we describe three cases of Sneddon's syndrome including clinical, neuroimaging and neuropathological features.

\section{METHOD}

The cases were followed up in the Neurology Division of the Hospital das Clínicas of Federal University of Paraná (UFPR) from 1992 to 2006. The patients underwent clinical and neurological examination (Table 1). Extensive laboratory analysis was performed. Echocardiography, transcranial doppler, cranial computed tomography (CT), magnetic resonance imaging of the brain (MRI) and cerebral angiography were also carried out. Diagnosis was based on the presence of livedo reticularis and ischemic cerebral events, as evidenced by clinical history, neurological and clinical examination and neuroimaging tests. In the first patient this was also evidenced by autopsy, which included macroscopic and microscopic analysis. The sections were stained with hematoxylin and eosin (H\&E) and other routine stains. The limitation of this study is that we did not determine the factor $V$ of Leiden mutations in our patients.

All subjects, or family of them, provided written informed consent, as required by appropriate local (and national) committees on the protection of research subjects.

\section{Cases}

Case 1 - A 24-year-old woman with a history of epilepsy and repeated strokes, of which the first at the age of 18 years, was referred to the Neurology Division of the Hospital das Clínicas (UFPR) for study. Five years later her first stroke, the patient had a new episode and was admitted to hospital with right hemiplegia, right-central fa-

Table 1. Clinical and epidemiological features of three cases of Sneddon's syndrome.

\begin{tabular}{lccc}
\hline Clinical features & Case \# 1 & Case \# 2 & Case \# 3 \\
\hline Gender & Female & Female & Female \\
Age & 24 years & 29 years & 42 years \\
Previous stroke & First at 18 years & First at 29 years & Yes \\
History of livedo & Since childhood & + & + \\
History of spontaneous abortion & One & Two & One \\
History of smoking & - & + & + \\
\hline
\end{tabular}

(+) yes, (-) no.

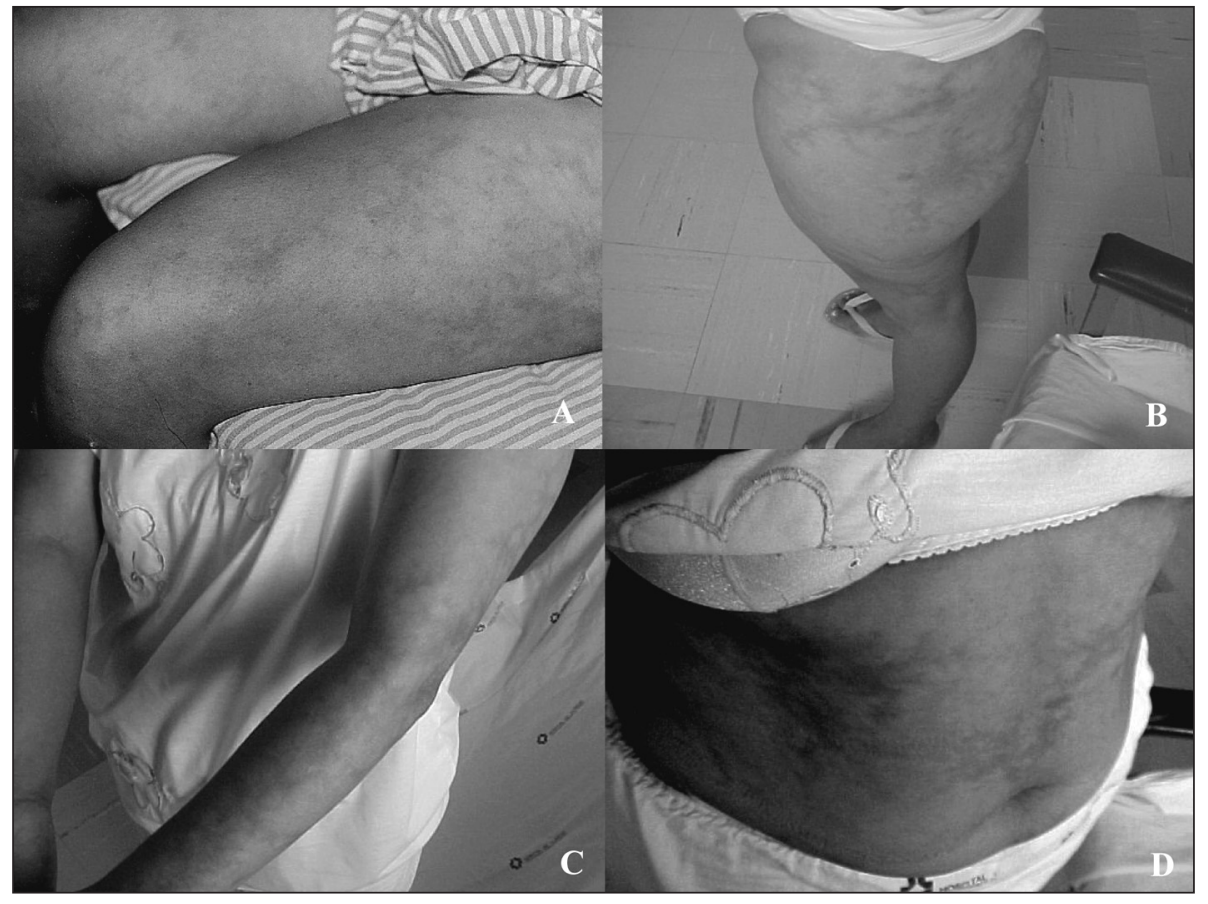

Fig 1. Skin showing livedo reticularis on the lower extremities in patient number one $(A)$ and on different parts of the body in patient number three $(B, C, D)$. 


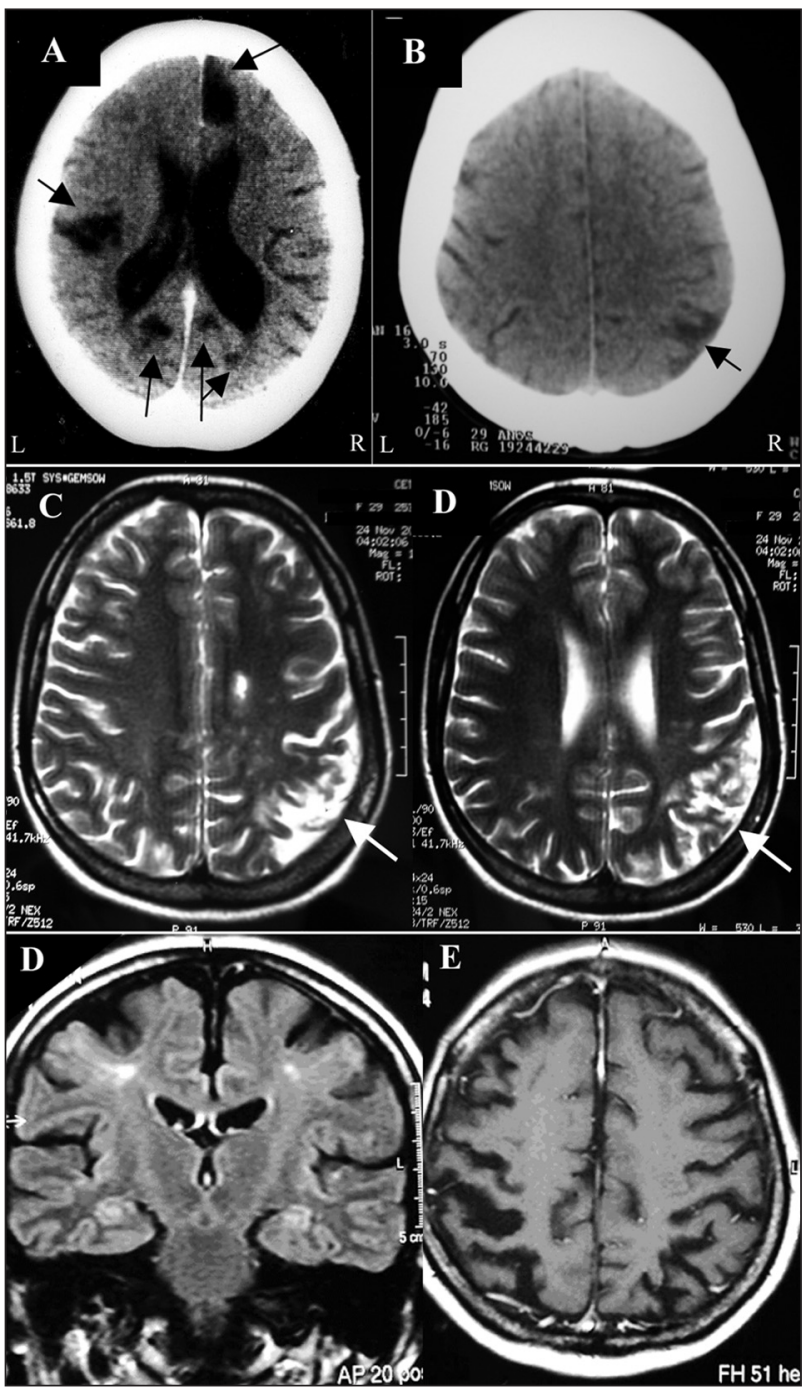

Fig 2. Cranial CT showing volumetric reduction of the cerebral hemispherium and hypodense areas in the right-temporal, leftfrontal and bilateral occipital regions compatible with infarctions (arrows) in patient number one (A) and an area of cerebral infarction in the left parietal region (arrows) in patient number two (B). T2-weighted MRI showing area in keeping with cranial CT (arrows) in patient number two (C) and cerebral atrophy with anomalous signals in the subcortical white matter in patient number three in coronal (D) and axial sections (E).

cial palsy, aphasia and dysphagia. Livedo reticularis was observed, particularly on the arms and legs (Fig 1A). Cranial CT showed ischemic strokes (Fig 2A). Acetylsalicylic acid was maintained, and treatment with corticoids, oral anticoagulants and anti-hypertensive agents was introduced. The patient was discharged from hospital with a diagnosis of Sneddon's syndrome.

Four weeks later the patient started to develop holocranial headache followed by decreased consciousness. Her blood pressure was $170 / 110 \mathrm{mmHg}$ at admission. The neurological examination showed mental confusion, dysphasia, dysphagia, left facial paralysis with crural paraparesis, spasticity on the right side, bilateral extensor plantar re-
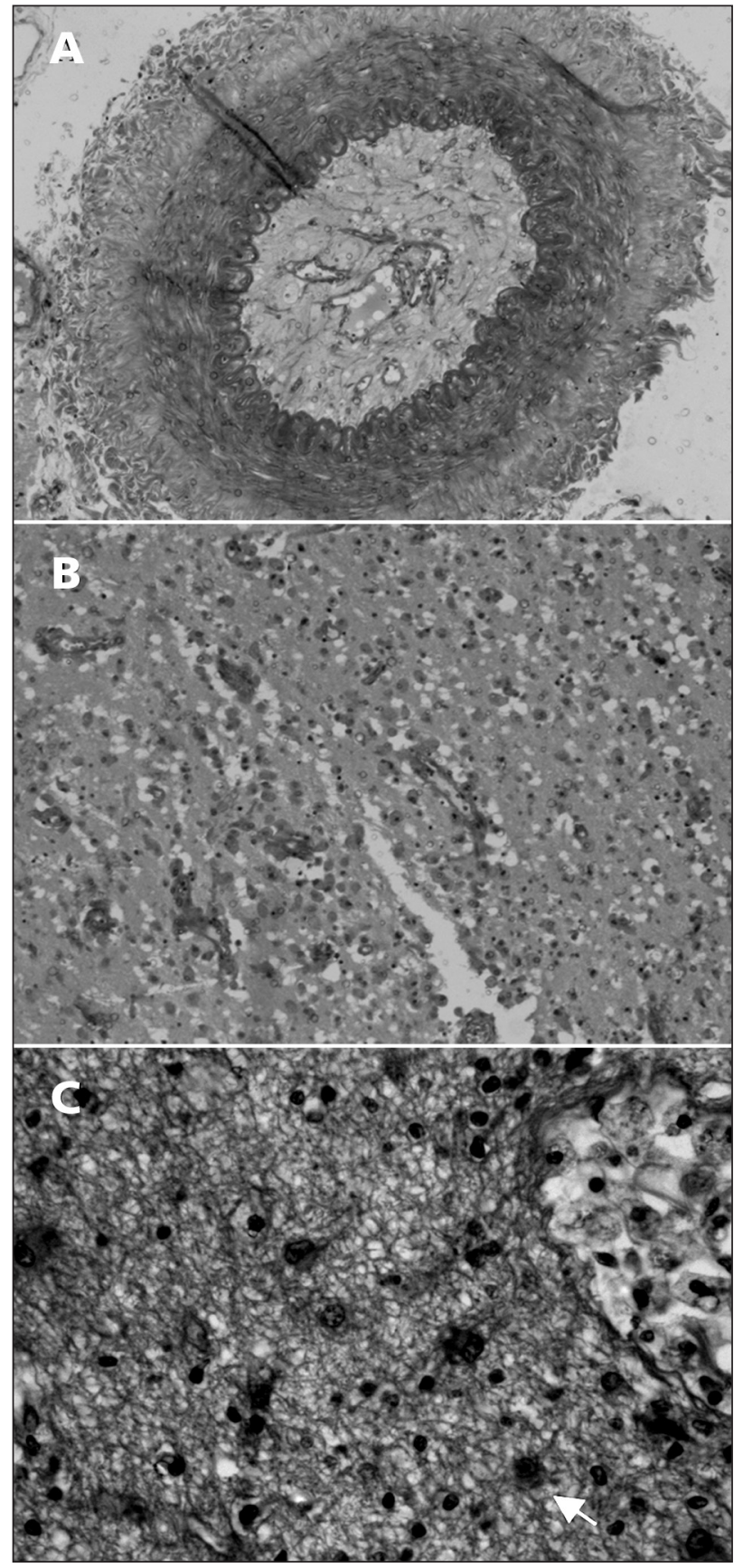

Fig 3. Cerebral microscopy in patient number one shows organized thrombosis in small and medium-caliber arteries with recanalization (H\&E, original magnification: $x 100)(A)$; areas of recent infarction with alteration of the usual staining characteristics, liquefactive necrosis and lipid-laden histiocytes (H\&E, original magnification: $x 100)(B)$; and areas of old infarctions with gliosis and a large number of gemistocytic astrocytes (arrow) (H\&E, original magnification: $x 400)$ (C).

sponse, generalized hyperreflexia and bilateral Hoffmann's sign. The results of cranial CT and blood tests are shown in Tables 2 and 3.

On the eleventh and twenty-first days after hospitalization, the patient developed urinary bleeding, epistaxis and 
Table 2. Blood tests of three patients with Sneddon's syndrome.

\begin{tabular}{|c|c|c|c|}
\hline Tests & Case \# 1 & Case \# 2 & Case \# 3 \\
\hline Anticardiolipin antibodies & Negative & $\begin{array}{l}\operatorname{lgG} 13.1 \mathrm{GPL} \\
\operatorname{lgM} 22.4 \mathrm{MPL}\end{array}$ & $\begin{array}{l}\text { IgG negative } \\
\text { IgM } 11.7 \mathrm{MPL}\end{array}$ \\
\hline Lupus anticoagulant & Negative & Negative & Slightly positive \\
\hline VDRL & Negative & $1: 4$ & Negative \\
\hline FTA-Abs & - & IgG and IgM negative & - \\
\hline Antinuclear factor & Negative & $\begin{array}{c}\text { 1:160 (multiple } \\
\text { nuclear dot pattern) }\end{array}$ & Negative \\
\hline Anti-DNA antibody & Negative & - & Negative \\
\hline Anti-SM/anti-RNP/Anti-La and anti-Ro antibodies & - & Negative & - \\
\hline Rheumatoid factor & - & Normal & - \\
\hline LE cells & Negative & Negative & - \\
\hline Platelet count & $18,000-36,000$ & $17,000-64,000$ & 150,000 \\
\hline $\mathrm{C}$ and $\mathrm{S}$ proteins & - & - & $\begin{array}{c}\text { C protein normal } \\
\text { S protein } 185 \% \\
\text { (VR } 70-123 \%)\end{array}$ \\
\hline Antithrombine III & - & - & Normal \\
\hline $\mathrm{C} 3-\mathrm{C} 4-\mathrm{CH} 50$ & Normal & Normal & Normal \\
\hline HIV serology & Negative & Negative & Negative \\
\hline Cytomegalovirus, listeria and toxoplasmosis serology & Negative & Negative & - \\
\hline Hepatitis B and C serology & - & Negative & - \\
\hline Lactic acid & Normal & Normal & _ \\
\hline Thyroid function & Normal & Normal & - \\
\hline C-reactive protein & - & Normal & Normal \\
\hline Blood sedimentation rate & - & Normal & Normal \\
\hline Cerebrospinal fluid & Normal & Normal & Normal \\
\hline
\end{tabular}

Table 3. Neuroradiologic and pathological features of three patients with Sneddon's syndrome.

\begin{tabular}{|c|c|c|c|}
\hline Tests & Case \# 1 & Case \# 2 & Case \# 3 \\
\hline Cranial CT & $\begin{array}{l}\text { Hypodense areas in right tem- } \\
\text { poral, left parietal and bilater- } \\
\text { al occipital regions (at } 18 \text { years } \\
\text { of age); also volumetric reduc- } \\
\text { tion of cerebral hemispherium } \\
\text { (at } 27 \text { years of age) }\end{array}$ & $\begin{array}{l}\text { Prominent sulci in left pari- } \\
\text { etal region suggestive of se- } \\
\text { quel, and a small right pari- } \\
\text { etal calcification }\end{array}$ & Cerebral atrophy \\
\hline Arteriography & $\begin{array}{l}\text { Occlusions in rami of left mid- } \\
\text { dle cerebral artery }\end{array}$ & - & $\begin{array}{l}\text { Distal slowness of reduced-cal- } \\
\text { iber cerebral arteries and pari- } \\
\text { etal irregularity suggestive of } \\
\text { vasculitis }\end{array}$ \\
\hline Brain MRI & - & $\begin{array}{l}\text { Hyperintense signals on T2- } \\
\text { weighted and FLAIR imag- } \\
\text { es in cortical and subcorti- } \\
\text { cal regions of the left pari- } \\
\text { etal lobe }\end{array}$ & $\begin{array}{l}\text { Cerebral atrophy with anom- } \\
\text { alous signals in the subcortical } \\
\text { white substance }\end{array}$ \\
\hline Echocardiography & Normal & $\begin{array}{l}\text { Slightly thick extremity of } \\
\text { anterior mitral-valve leaflet }\end{array}$ & $\begin{array}{l}\text { Left ventricular hypertrophy } \\
\text { with mitral valve stenosis }\end{array}$ \\
\hline $\begin{array}{l}\text { Vascular ultrasonography of } \\
\text { carotid and vertebral arteries }\end{array}$ & Normal & Normal & Normal \\
\hline Transcranial doppler & Normal & $\begin{array}{l}\text { Compensatory vasodilata- } \\
\text { tion of right middle and an- } \\
\text { terior cerebral arteries }\end{array}$ & - \\
\hline
\end{tabular}


upper digestive hemorrhage followed by hypotension. On the fifty-third day the patient had subconjunctival haemorrhage, ecchymosis on the arms, legs and trunk, and massive proteinuria. Two days later the patient had alternate periods of apathy and psychomotor agitation. The following day, despite the treatment, she progressed to shock followed by death.

The post-mortem examination revealed recent cerebral infarctions located in the left frontal pole (measuring $4 \times 4$ $x 4 \mathrm{~cm})$, the right-anterior cerebral-artery territory $(5 \times 4 \times$ $2 \mathrm{~cm}$ ) and the right hippocampus. There were also old cerebral infarctions in the left-anterior cerebral-artery territory and in the temporal, occipital and insular regions. Cerebral sulci and ventriculi were enlarged, but the cerebral gyri were narrowed. No areas of hemorrhage were found. The cerebellum and brainstem had no abnormalities. Microscopy also showed important cerebral alterations (Fig 3). Acute thrombotic non-infectious endocarditis of the mitral valve with fibrosis, suggesting a recurrent process, as well as pericardial effusion $(200 \mathrm{~mL})$ and cardiac ventricular hypertrophy (heart weight, $350 \mathrm{~g}$ ) were found. Membranoproliferative glomerulonephropathy with hyaline tubular vacuolar degeneration and hyaline casts as well as mild renal arteriolosclerosis with old infarctions and acute hemorrhagic cystitis were also observed.

Case 2 - A 29-year-old woman was referred with right hemiplegia, and hemiparesthesia. Two years before the stroke, the patient presented thrombocytopenia $(50,000$ platelets $/ \mu \mathrm{L}$ ) and a history of two spontaneous abortions. Although she used prednisone for six months, platelet count did not increase. Clinical examination showed livedo reticularis, Raynaud's phenomenon and muscle strength grade IV on the right side. The results of blood and neuroradiologic tests are shown in Tables 2 and 3 and Figs 2B and $2 \mathrm{C}$.

Heparin was replaced by oral anticoagulant, but the patient continues to suffer from thrombocytopenia and is being assisted in the outpatient ward.

Case 3 - A 42-year-old woman with a history of epilepsy and two stroke events was admitted to the Neurology Division for investigation. At admission the patient presented with right hemiparesis, right hemiparesthesia and secondary headache. The patient had a history of spontaneous abortion and hypertension and had taken carbamazepine $200 \mathrm{mg}$ tid, phenytoin $300 \mathrm{mg}$ qd, asperin $100 \mathrm{mg}$ qd and captopril $25 \mathrm{mg}$ bid. Clinical examination revealed livedo reticularis (Figs 1B, 1C and 1D), Raynaud's phenomenon and reduced muscle strength on the right side. Blood and neuroradiologic tests are shown in Tables 2 and 3 and Figs 2D and $2 \mathrm{E}$.

\section{DISCUSSION}

Patients with ischemic cerebrovascular events, livedo reticularis and antiphospholipid antibodies are considered by some authors to have primary antiphospholipid syndrome ${ }^{6,18-20}$ while for other authors these antibodies are involved in the pathogenesis of Sneddon's syndrome ${ }^{3}$. Studies of patients with Sneddon's syndrome revealed elevated antiphospholipid-antibody levels in $57 \%$ of patients matched with normal controls ${ }^{11}$. However, in some patients these antibodies are repeatedly not found ${ }^{20,21}$, indicating that Sneddon's syndrome may be a distinct entity or perhaps a group of different disorders ${ }^{14}$ because there are clinical differences in patients with or with-

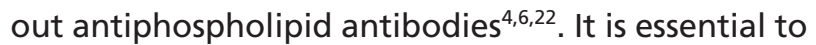
keep this point in mind, as some important clinical features that are described in patients with Sneddon's syndrome are found in patients with primary antiphospholipid syndrome or systemic lupus erythematosus $^{4,23}$.

According to Francès and Piette ${ }^{4}$, thrombocytopenia is a common feature of primary antiphospholipid syndrome and of Sneddon's syndrome in patients with antiphospholipid antibodies, but is not a feature of cases in which these antibodies are not found. This could explain the persistent thrombocytopenia observed in the second patient, as thrombocytopenia, livedo reticularis and stroke are described in a large number of patients with antiphospholipid syndrome ${ }^{23,24-26}$. However, venous thrombosis was not found in these three patients although it is an important feature of antiphospholipid syndrome ${ }^{23,26}$.

The first and third patients had cerebral atrophy, which is described in Sneddon's syndrome as a progressive complication due to involvement of small arteries $^{20}$. Nonetheless, in primary antiphospholipid syndrome the neurological findings are stable because the affected arteries are larger than those affected in Sneddon's syndrome ${ }^{20}$. However, the absence of cerebral atrophy in the second patient does not exclude a diagnosis of Sneddon's syndrome.

Other features described in Sneddon's syndrome ${ }^{3,4,6-8}$ were also found in these three patients and contributed to the diagnosis; these included hypertension, renal and cardiac disorders, Raynaud's phenomenon, seizures and a history of spontaneous abortions. The first patient had livedo reticularis and seizures for the first time during her childhood, as described in Sneddon's syndrome ${ }^{3,7}$.

Although the pathogenesis of Sneddon's syndrome with the presence of antiphospholipid antibodies may be explained in a similar manner to the pathogenesis of antiphospholipid syndrome $e^{27-30}$, the significance of the presence of these antibodies in both syndromes is unclear ${ }^{31,32}$.

These three cases illustrate the importance and 
severity of Sneddon's syndrome as well as the importance of the differential diagnosis of ischemic cerebrovascular events in young patients, particularly in cases where antiphospholipid antibodies cannot be detected.

\section{REFERENCES}

1. Champion RH, Rook A. Livedo reticularis. Proc R Soc Med 1960;53:961962.

2. Sneddon IB. Cerebrovascular lesions and livedo reticularis. Br J Dermatol 1965;77:180-185.

3. Bolayir E, Yilmaz A, Kugu N, Erdogan H, Akyol M, Akyuz A. Sneddon's syndrome: clinical and laboratory analysis of 10 cases. Acta Med Okayama 2004;58:59-65.

4. Francés C, Piette JC. The mystery of Sneddon syndrome: relationship with antiphospholipid syndrome and systemic lupus erythematosus. J Autoimmun 2000;15:139-143.

5. Boesch SM, Plörer AL, Auer AJ et al. The natural course of Sneddon's syndrome: clinical and magnetic resonance imaging findings in a prospective six year observation study. J Neurol Neurosurg Psychiatry 2003;74:542-544.

6. Kalashnikova LA, Nasonov EL, Kushekbaeva AE, Gracheva LA. Anticardiolipin antibodies in Sneddon's syndrome. Neurology 1990;40:464-467.

7. Flöel A, Imai T, Lohmann H, Bethke F, Sunderkötter C, Droste DW. Therapy of Sneddon's syndrome. Eur Neurol 2002;48:126-132.

8. Macário F, Macário MC, Ferro A, Gonçalves F, Campos M, Marques A. Sneddon's syndrome: a vascular systemic disease with kidney involvement? Nephron 1997;75:94-97.

9. Stockhammer G, Felber SR, Zelger B, et al. Sneddon's syndrome: diagnosis by skin biopsy and MRI in 17 patients. Stroke 1993;24:685-690.

10. Geschwind DH, FitzPatrick M, Mischel PS, Cummings JL. Sneddon's syndrome is a thrombotic vasculopathy: neuropathologic and neuroradiologic evidence. Neurology 1995;45:557-560.

11. Kalashnikova LA, Korczyn AD, Shavit S, Rebrova O, Reshetnyak T, Chapman J. Antibodies to prothrombin in patients with Sneddon's syndrome. Neurology 1999;53:223-225.

12. Tietjen GE, Al-Qasmi MM, Gunda P, Herial NA. Sneddon's syndrome: another migraine-stroke association? Cephalalgia 2006;26:225-232.

13. Zaccariotti VA, Martins LF, da Costa V, Silva NA, da Casas AA, de Melo-Souza SE. Sneddon's syndrome: report of 3 cases. Arq Neuropsiquiatr 1995;53:82-87.

14. Karagülle AT, Karadag D, Erden A, Erden I. Sneddon's syndrome: MR imaging findings. Eur Radiol 2002;12:144-146.

15. Hilton DA, Footitt D. Neuropathological findings in Sneddon's syndrome. Neurology 2003;60:1181-1182.
16. Aquino Gondim FA, Leacock RO, Subrammanian TA, Cruz-Flores $\mathrm{S}$. Intracerebral hemorrhage associated with Sneddon's syndrome: is ischemia-related angiogenesis the cause? Case report and review of the literature. Neuroradiology 2003;45:368-372.

17. Serrano-Pozo A, Gómez-Aranda F, Franco-Macías E, Serrano-Cabrera A. Hemorragia cerebral en el síndrome de Sneddon: caso clínico y revisión de la bibliografia. Rev Neurol 2004;39:731-733.

18. Sumi Y, Ozaki Y, Itoh S, Katayama H, Tanaka S. Cerebral blood flow-SPECT in a patient with Sneddon's syndrome. Ann Nucl Med 1999;13:109-112.

19. Levine SR, Langer SL, Albers JW, Welch KMA. Sneddon's syndrome: an antiphospholipid antibody syndrome? Neurology 1988;38:798-800.

20. Fetoni V, Grisoli M, Salmaggi A, Carriero R, Girotti F. Clinical and neuroradiological aspects of Sneddon's syndrome and primary antiphospholipid antibody syndrome: a follow-up study. Neurol Sci 2000;21: 157-164.

21. Szmyrka-Kaczmarek M, Daikeler T, Benz D, Koetter I. Familial inflamatory Sneddon's syndrome: case report and review of the literature. Clin Rheumatol 2005;24:79-82.

22. Francés C, Papo T, Wechsler B, Laporte JL, Biousse V, Piette JC. Sneddon's syndrome with or without antiphospholipid antibodies: a comparative study in 46 patients. Medicine (Baltimore) 1999;78:209-219.

23. Miyakis S, Lockshin MD, Atsumi T, et al. International consensus statement on an update of the classification criteria for definite antiphospholipid syndrome (APS). J Thromb Haemost 2006;4:295-306.

24. Hawkins C, Gatenby P, Tuck R, Danta G, Andrews C. Cerebrovascular disease associated with antiphospholipid antibodies: more questions than answers. J Autoimmune Dis 2006, 3:3, doi:10.1186/1740-2557-3-3 (available from: $<$ http://www.jautoimdis.com/content/3/1/3>)

25. Hachulla E, Leys D, Deleume JF, Pruvo JP, Devulder B. Manifestations neurologiques associées aux anticorps antiphospholipides: ou que reste-t-il du neurolupus? Rev Méd Interne 1995;16:121-130.

26. Cervera R, Piette J-C, Font J, et al. Antiphospholipid syndrome: clinical and immunologic manifestations and patterns of disease expression in a cohort of 1,000 patients. Arthritis Rheum 2002:46:1019-1027.

27. Sinharay R. Sneddon's syndrome: additional neurological feature in antiphospholipid (Hughes') syndrome. Postgrad Med J 2003;79:550.

28. Ruiz-Irastorza G, Khamashta MA. Stroke and antiphospholipid syndrome: the treatment debate. Rheumatology 2005;44:971-974.

29. Groot PG, Derksen RHMW. The antiphospholipid syndrome: clinical characteristics, laboratory features and pathogenesis. Curr Opin Infect Dis 2005;18:205-210

30. Ortel T. Thrombosis and the antiphospholipid syndrome. Hematology 2005:462-468.

31. Martins da Silva A, Rocha N, Pinto M, et al. Tremor as the first neurological manifestation of Sneddon's syndrome. Mov Disord 2005;20: 248-251.

32. Ayoub N, Esposito G, Barete S, Soria C, Piette J-C, Francès C. Protein Z deficiency in antiphospholipid-negative Sneddon's syndrome. Stroke 2004;35:1329-1332. 